\title{
Inhibition of shrimp pathogenic vibrios by extracellular compounds from a proteolytic bacterium Pseudomonas sp. W3
}

\author{
Pattamarat Rattanachuay \\ Department of Microbiology \\ Faculty of Science \\ Prince of Songkla University \\ Hat Yai, 90112, Thailand \\ Duangporn Kantachote* \\ Department of Microbiology \\ Faculty of Science \\ Prince of Songkla University \\ Hat Yai, 90112, Thailand \\ E-mail: duangporn.k@psu.ac.th \\ Manee Tantirungkij \\ Central Laboratory and Greenhouse Complex \\ Kasetsart University, Kamphaeng Sean Campus \\ Nakhon Pathom 73140, Thailand \\ Teruhiko Nitoda \\ The Graduate School of Natural Science and Technology \\ Okayama University \\ Okayama 7008530, Japan \\ Hiroshi Kanzaki \\ The Graduate School of Natural Science and Technology \\ Okayama University \\ Okayama 7008530, Japan \\ Website: http://www.psu.ac.th
}

Financial support: This work was supported by a Graduate School Songklanakarin Scholarship, 2007-2009, Graduate School and Faculty of Science, Prince of Songkla University, Thailand.

Keywords: bacteriolytic enzymes, bioactive compounds, Pseudomonas sp. W3, shrimp pathogenic bacteria, Vibrio spp.

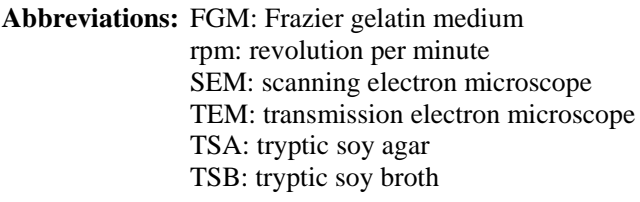

Pseudomonas sp. W3, a bacterium known to produce an extracellular alkaline protease, secreted secondary metabolites that inhibited pathogenic bacteria responsible for shrimp luminous vibriosis disease. Antivibrio compounds in the culture supernatant or culture filtrates $(0.45 \mu \mathrm{m}$ and $0.22 \mu \mathrm{m})$ of the isolate $\mathrm{W} 3$ were tested using an agar well diffusion method on a number of pathogenic vibrios. Vibrio harveyi PSU 2015 a pathogenic isolate was the most sensitive strain. The effectiveness of preparations from the isolate W3 against $V$. harveyi PSU 2015, and V. cholerae PSSCMI 0062 was in the order of culture supernatant $>0.45 \mu \mathrm{m}$ culture filtrate $>0.22 \mu \mathrm{m}$ culture filtrate. These extracellular antivibrio compounds also lysed both dead and living cells of $V$. harveyi PSU 2015. Results of the partial characterization tests indicated that there was some particulate antivibrio compound that was destroyed by treatment with enzymes particularly $\alpha$ chymotrypsin, autoclaving at $121^{\circ} \mathrm{C}$ for $15 \mathrm{~min}$ and was mostly removed by filtration through a $0.22 \mu \mathrm{m}$ filter. Most of the inhibitory compounds were of small molecular weight able to pass through a $0.22 \mu \mathrm{m}$ filter and were resistant to treatment with various enzymes, pH values between 4-8 and temperatures up to $121^{\circ} \mathrm{C}$ for $30 \mathrm{~min}$. The optimum $\mathrm{pH}$ for the antivibrio activity in the $0.45 \mu \mathrm{m}$ culture filtrate was between $\mathrm{pH}$ 6-7.

*Corresponding author 
Shrimp cultivation is one of the most economically important aquacultural activities in Asia, and South America but is also practiced worldwide (Nimrat et al. 2008). However, shrimp cultivation has faced many serious problems such as shrimp diseases, unsatisfactory practices i.e. inadequate control of water quality, etc. Viruses and bacteria are the main causes of shrimp diseases. Disease due to bacterial infections, particularly luminous vibriosis, is a major problem for shrimp cultivation in Asian countries (Musa et al. 2008) and if they can completely destroy hatchery productivity for extended periods (Gomez-Gil et al. 2000; Vinod et al. 2005). The causative agents of vibriosis include Vibrio harveyi, V. parahaemolyticus, $V$. cholerae and others (Austin and Zhang, 2006; Won and Park, 2008). Among vibrios, $V$. harveyi is the main cause of shrimp death, infecting larva in the hatchery as well as shrimp in the cultivation pond (Vinod et al. 2005; Chari and Dubey, 2006). The virulence of $V$. harveyi has at times caused a $100 \%$ loss in shrimp production (Chythanya et al. 2002; Musa et al. 2008). V. harveyi is also a serious pathogen for a wide range of marine animals and in other aquaculture systems (Austin and Zhang, 2006).

Antibiotics such as tetracycline, chloramphenical, oxolinic acid, and norfoxazine (Holmström et al. 2003) have been commonly used to control these shrimp diseases. In many cases, their extensive use has led to a decrease in the therapeutic efficiency of the least expensive antibiotics, so during the past decade many Asian aquaculture programs have gradually switched to the use of broad spectrum antibiotics such as chloramphenicol (Huys et al. 2007). However recently, in Thailand some antibiotics such as chloramphenical and the group of nitrofurans (furazolidone, nitrofurazone and nitrofurantion) have been banned for use in shrimp cultivation due to the retention of antibiotics residues in aquaculture products (Gräslund et al. 2002). There is also evidence of the development of bacterial resistance to a number of antibiotics i.e. ampicillin and sulphamethoxazole (Musa et al. 2008). Therefore, for the important shrimp pathogenic bacteria like Vibrio harveyi, it is important to carry out laboratory testing for the sensitivity of an isolated known shrimp pathogen to different antibiotics and compounds, particularly those that could be used in shrimp aquaculture. Based on the above information in order to limit the use of antibiotics, many workers have been exploring the use of new bioactive compounds for controlling bacterial diseases of shrimp, particularly that caused by $V$. harveyi.

Pseudomonads are attractive bacteria for testing as sources of new bioactive compounds including antibiotics, bacteriocins, biosurfactants and bacteriolytic enzymes (Vijayan et al. 2006; Kumar et al. 2008; Sivaprakasam et al. 2008). They are widely distributed in soil and aquatic habitats including shrimp ponds (Sakami et al. 2008). There have been reports that Pseudomonas spp. produce bioactive compounds with ability to control vibrios such as $V$. harveyi and $V$. parahaemolyticus, and that have no effect

Table 1. The susceptibility of Vibrio harveyi strains to antibiotics ( $\mathrm{mm}$ of inhibition zone).

\begin{tabular}{|c|c|c|c|c|}
\hline & Disk content & \multicolumn{3}{|c|}{ Vibrio harveyi } \\
\cline { 4 - 5 }$(\boldsymbol{\mu}$ Antimicrobial agent & PSU 2015 & AAHRC1 & AAHRC2 \\
\hline Ampicillin & 10 & $\mathrm{R}(0)$ & $\mathrm{R}(0)$ & $\mathrm{R}(0)$ \\
\hline Kanamycin & 30 & $\mathrm{R}(13)$ & $\mathrm{R}(11)$ & $\mathrm{R}(12)$ \\
\hline Furazolidone & 15 & $\mathrm{~S}(18)$ & $\mathrm{I}(17)$ & $\mathrm{I}(17)$ \\
\hline Sulphamethoxazone-trimethoprim & 25 & $\mathrm{~S}(21)$ & $\mathrm{I}(13)$ & $\mathrm{I}(13)$ \\
\hline Chloramphenicol & 30 & $\mathrm{~S}(31)$ & $\mathrm{S}(25)$ & $\mathrm{S}(26)$ \\
\hline Oxolinic acid & 2 & $\mathrm{~S}(19)$ & $\mathrm{S}(18)$ & $\mathrm{S}(20)$ \\
\hline Tetracycline & 30 & $\mathrm{~S}(27)$ & $\mathrm{S}(23)$ & $\mathrm{S}(23)$ \\
\hline Nalidixic acid & 30 & $\mathrm{~S}(25)$ & $\mathrm{S}(23)$ & $\mathrm{S}(24)$ \\
\hline Norfoxazine & 10 & $\mathrm{~S}(21)$ & $\mathrm{S}(21)$ & $\mathrm{S}(23)$ \\
\hline
\end{tabular}

R (resistant); I (intermediate); S (susceptible). 


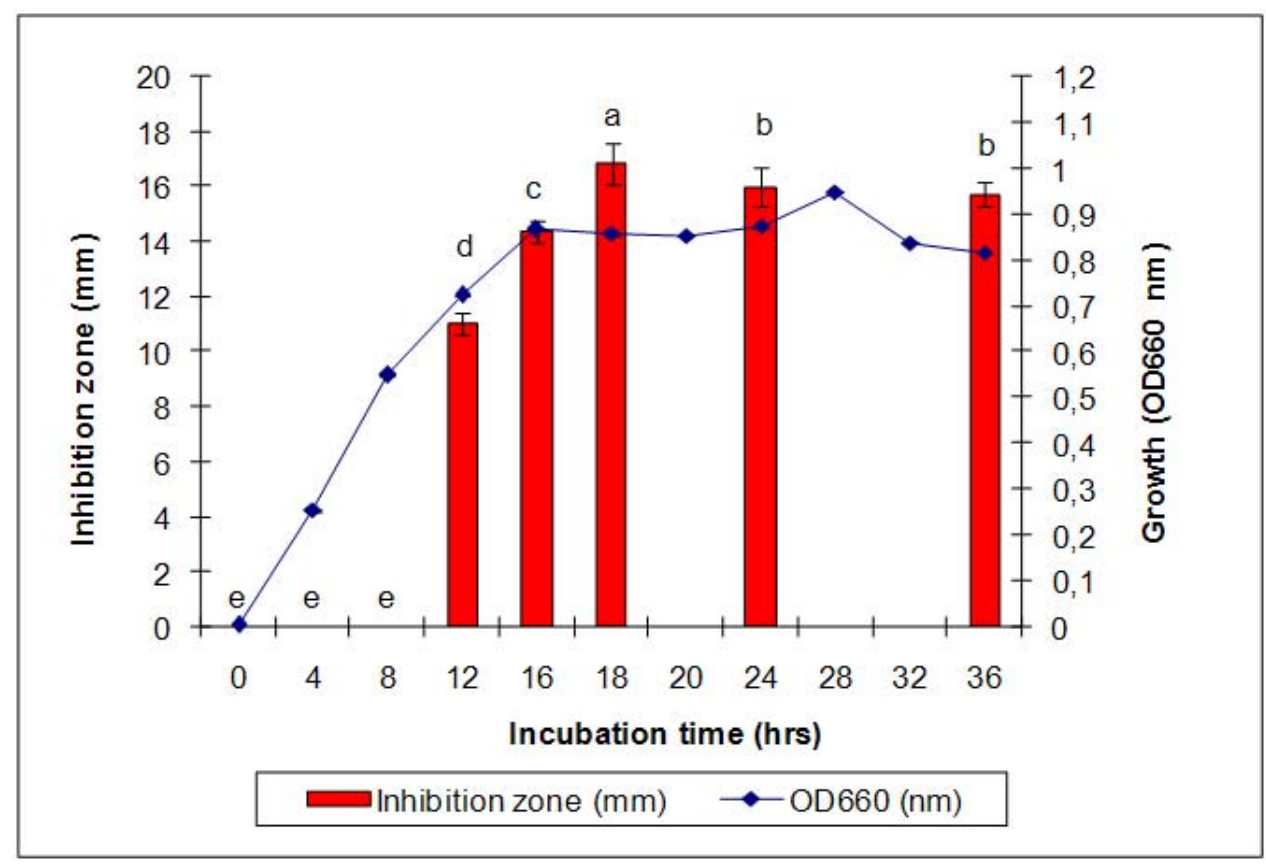

Figure 1. Growth of Pseudomonas sp. W3 in FGM medium plus $2 \% \mathrm{NaCl}$ and its inhibitory effect on the growth of Vibrio harveyi PSU 2015. Different letters above the bars indicate significant differences $(p<0.05)$.

on the shrimp (Chythanya et al. 2002; Vijayan et al. 2006). One of our isolates, Pseudomonas sp. W3 is a proteolytic bacterium and is also able to control $V$. harveyi during white shrimp (Litopenaeus vannamei) cultivation with no harm to shrimp (Rattanachuay et al. 2007). The results prompted us to explore its ability to produce compounds that could control shrimp pathogens like vibrios. Hence, the aims of this study were to produce an antibiogram of pathogenic Vibrio harveyi strains commonly found in Thailand, to investigate the spectrum of anti-vibrio compounds produced by Pseudomonas sp. W3 and to characterize their actions against $V$. harveyi including the possibility that they might be useful as alternative biocontrol agents in shrimp cultivation.

\section{MATERIALS AND METHODS}

\section{Bacterial strains used}

Pseudomonas sp. W3 was isolated on Frazier gelatin medium (FGM) (Frazier and Rupp, 1982) from a water sample collected from an intensive shrimp cultivation pond in Pattanee province, Thailand. The following shrimp pathogens; $V$. harveyi AAHRC 1, $V$. harveyi AAHRC 2, $V$. parahaemolyticus AAHRC 1, V. harveyi PSU 2015, V. parahaemolyticus PSU 1681 and $V$. cholerae PSSCMI 0062 were provided by the Aquatic Animal Help Research Center (AAHRC), Prince of Songkla University and Assoc. Prof. Dr. Varaporn Vuddhakul, Department of Microbiology, Faculty of Science, Prince of Songkla University. All shrimp pathogens were isolated from shrimp samples infected by vibrios.

\section{Preparation of culture supernatant and culture filtrates for antivibrio activity testing}

The isolate Pseudomonas sp. W3 was grown in FGM plus $2 \% \mathrm{NaCl}$ under optimal conditions $\left(30^{\circ} \mathrm{C}, 150 \mathrm{rpm}\right)$ for 18 hrs (Rattanachuay et al. 2007). The culture broth was centrifuged at $6000 \mathrm{rpm}$ for 25 min (SANYO, Harrier 18/80 Refrigerator; U.K.) to remove bacterial cells and provide the culture supernatant. A portion of the culture supernatant was then filtered through either a $0.45 \mu \mathrm{m}$ or $0.22 \mu \mathrm{m}$ pore size cellulose acetate filter to provide the culture filtrates used for testing. It was hoped that the $0.22 \mu \mathrm{m}$ filter would remove any particulate cell debris so that this culture filtrate would contain only truly soluble chemicals and colloidal organic matter. The inhibition of shrimp pathogenic bacteria, by these culture samples (culture supernatant and culture filtrates), were separately tested by the agar well diffusion method. The shrimp pathogenic bacteria were all cultivated in TSB (Tryptic soy broth; Difco, USA) plus $1.5 \% \mathrm{NaCl}$ and shaken (Gallenkamp, orbital incubator) at $150 \mathrm{rpm}, 30^{\circ} \mathrm{C}$ for $18 \mathrm{hrs}$ to use for inoculation of the test plates.

\section{Inhibition of shrimp pathogens by antibiotics and culture samples of Pseudomonas sp. W3}

The antibiotics in Table 1, commonly used in aquaculture in Asian countries such as Malaysia and Thailand were chosen for investigating their effects on an isolated bacterial shrimp pathogen. Some of these antibiotics have recently been banned (furazolidone, chloramphenicol, oxolinic acid and tetracycline) (Gräslund et al. 2002; 
Holmstrom et al. 2003; Musa et al. 2008). Only three strains of $V$. harveyi were used to produce their antibiograms because they are the usual cause of vibriosis (as previously described) they are virulent strains and frequently found in infected shrimp from hatcheries and cultivation ponds. Samples from Pseudomonas sp. W3 or antibiotics (Table 1) were tested by the agar well diffusion method for inhibition of the vibrios as follows: shrimp pathogens in TSB plus $1.5 \% \mathrm{NaCl}$ were individually adjusted to the 0.5 McFarland standard (bio Merieux; 69280 Marcy l'Etoile, France) and then swabbed over the surface of TSA plus $1.5 \% \mathrm{NaCl}$ plates. Antibacterial disks (Table 1) were placed evenly over the surface of the plate with forceps. Wells (diameter $7 \mathrm{~mm}$ ) were punched in the TSA plate by a Pasteur pipette (3 wells/plate). Seventy $\mu \mathrm{l}$ of the different culture samples from the isolate W3 was transferred into each well and the diffusion of culture samples into the agar could be visually observed. All plates were incubated at $30^{\circ} \mathrm{C}$ for 24 hrs and the diameter of the inhibition zones was measured using a Vernier caliper.

\section{Effect of culture age on production of antivibrio compounds}

Pseudomonas sp. W3 was cultured in FGM medium supplement with $2 \% \mathrm{NaCl}$ under the optimal conditions as mentioned previously. The culture broth was sampled at 0 , $4,8,12,16,18,24$ and 36 hrs to measure growth based on cell turbidity at $660 \mathrm{~nm}$ (OD 660) using a spectrophotometer and each sample was then filtered using a $0.45 \mu \mathrm{m}$ cellulose acetate filter and tested by the agar well diffusion method for inhibitory activity against $V$. harveyi PSU 2015.

\section{Assay of bacteriolytic activity}

The $0.45 \mu \mathrm{m}$ culture filtrate prepared from either an 18 or
24 hrs culture of Pseudomonas sp. W3 was used to test its bacteriolytic activity using a method previously described by Than et al. (2004). A 48 hrs culture of $V$. harveyi PSU 2015 was centrifuged at $6000 \mathrm{rpm}$ for $25 \mathrm{~min}$ to obtain the cell pellet. This was dispersed in $3 \mathrm{ml}$ of sterile Artificial Sea Water (ASW) and incubated in a water bath at $50^{\circ} \mathrm{C} \pm$ $0.5^{\circ} \mathrm{C}$ for $30 \mathrm{~min}$ to obtain heat-killed cells. A mixture consisting of $7 \mathrm{ml}$ of the $0.45 \mu \mathrm{m}$ culture filtrate from the isolate $\mathrm{W} 3$ and $3 \mathrm{ml}$ of the heat-killed $V$. harveyi cell suspension in sterile ASW was adjusted to an initial absorbance of approximately 0.5 (OD $540 \mathrm{~nm}$ ) using a spectrophotometer and then incubated at $30^{\circ} \mathrm{C}$ for investigating cell lytic activity. The cell lytic activity was assayed by monitoring the absorbance at $540 \mathrm{~nm}$ at different times; 0, 2, 4, 6, 8, 10 and 22 hrs and the ASW was used as a blank. A 24 hrs culture filtrate W3 was also used to test its bacteriolytic activity against live cells of $V$. harveyi PSU 2015 by using the same method as for heatkilled cells, except that dead cells was replaced by live cells. Both live cells and dead cells of a target organism were used to investigate the lytic activity of the isolate W3 due to previous reports that different amounts of lytic activities were detected when comparing dead and live cells (Guilloux-Benatier et al. 2000; Ryazanova et al. 2005). In addition, another reason was that one of the aims of some study was to use lytic enzymes to break dead cells for use as a source of nutrients (Wahid et al. 2007) and in this study the main aim was to test for lytic activity in the hope that it might be used to control a shrimp pathogenic bacterium such as $V$. harveyi.

Lytic activity was ranked into four levels according to the percentage decrease in absorbance at $540 \mathrm{~nm}$ in comparison with the control: -, 0-24\%; +, 25-49\%; ++, 50-74\% and ,$+++ 75-100 \%$ (Niwa et al. 2005). In addition, a scanning electron microscope (SEM) was used to observe the cells obtained from both live and dead cell experiments and a

Table 2. Inhibition of shrimp pathogens by samples from the culture supernatant and culture filtrates of Pseudomonas sp. W3.

\begin{tabular}{|c|c|c|c|}
\hline \multirow{2}{*}{ Shrimp pathogen } & \multicolumn{3}{|c|}{ Inhibition zone (mm) } \\
\cline { 2 - 4 } & Supernatant & $\mathbf{0 . 4 5} \boldsymbol{\mu m}$ culture filtrate & $\mathbf{0 . 2 2} \boldsymbol{\mu m}$ culture filtrate \\
\hline V. harveyi PSU 2015 & $21.2 \pm 0.4^{\mathrm{a}}$ & $18.0 \pm 0.4^{\mathrm{b}}$ & $15.4 \pm 0.4^{\mathrm{c}}$ \\
\hline V. harveyi AAHRC 1 & $15.3 \pm 0.4^{\mathrm{a}}$ & $15.3 \pm 0.4^{\mathrm{a}}$ & $14.4 \pm 0.7^{\mathrm{b}}$ \\
\hline V. harveyi AAHRC 2 & $14.5 \pm 0.5^{\mathrm{ab}}$ & $14.7 \pm 0.7^{\mathrm{a}}$ & $13.2 \pm 0.6^{\mathrm{b}}$ \\
\hline V. parahaemolyticus AAHRC1 & $13.7 \pm 0.8^{\mathrm{a}}$ & $12.8 \pm 0.6^{\mathrm{b}}$ & $12.8 \pm 0.4^{\mathrm{b}}$ \\
\hline V. parahaemolyticus PSU1681 & $6.5 \pm 0.2^{\mathrm{a}}$ & $0 \pm 0^{\mathrm{b}}$ & $0 \pm 0^{\mathrm{b}}$ \\
\hline V. cholerae PSSCMI 0062 & $16.5 \pm 0.6^{\mathrm{a}}$ & $10.9 \pm 0.5^{\mathrm{b}}$ & $10.0 \pm 0.6^{\mathrm{c}}$ \\
\hline
\end{tabular}

Mean value \pm standard deviation of nine observations. Different letters in the same row indicate significant differences $(p<0.05)$. 


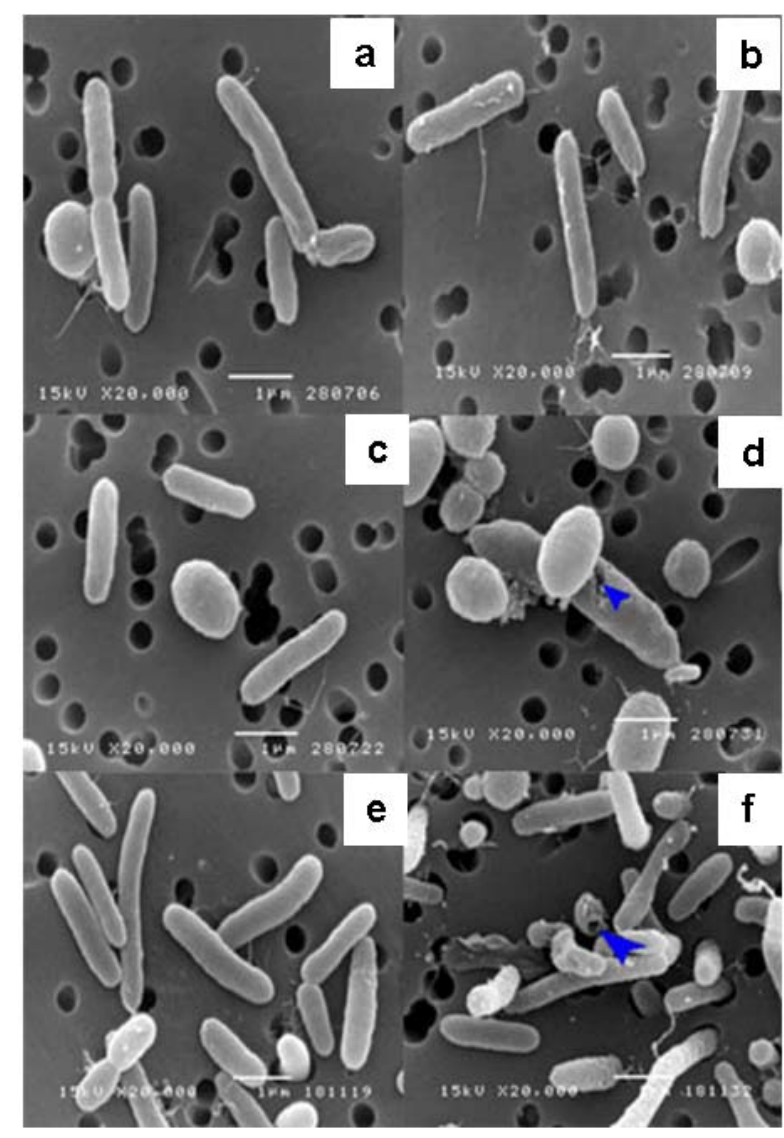

Figure 2. SEM photomicrographs showing lysis of heat killed cells ( $a, b, c$ and $d)$ and live cells (e and $f$ ) of Vibrio harveyi PSU 2015 by a $24 \mathrm{hrs}$ culture filtrate $(0.45 \mu \mathrm{m})$ of Pseudomonas sp. W3. (a) control (no addition) at $0 \mathrm{hr}$; (b) control at 22 hrs; (c) treatment at $0 \mathrm{hr}$; (d) treatment after 22 hrs incubation; (e) treatment at $0 \mathrm{hr}$ and (f) treatment after $22 \mathrm{hrs}$ incubation. The arrows show the presence of holes on cells.

transmission electron microscopy (TEM) for the live culture experiments using the manufacturers protocols.

\section{Preliminary studies on the property of bioactive compounds from Pseudomonas sp. W3}

The culture filtrates $(0.45$ and $0.22 \mu \mathrm{m})$ of Pseudomonas sp. W3 were separately tested for protein characteristics by treatment with proteinase $\mathrm{K}\left(1 \mathrm{mg} / \mathrm{ml}\right.$ at $\left.30^{\circ} \mathrm{C}\right)$ (Fluka), pronase $\left(2 \mathrm{mg} / \mathrm{ml}\right.$ at $30^{\circ} \mathrm{C}$ ) (Fluka), $\alpha$-chymotrypsin (5 $\mathrm{mg} / \mathrm{ml}$ at $30^{\circ} \mathrm{C}$ ) (Fluka), trypsin $\left(50 \mathrm{mg} / \mathrm{ml} 30^{\circ} \mathrm{C}\right.$ ) (Fluka) and lysozyme (1 $\mathrm{mg} / \mathrm{ml}$ at $\left.25^{\circ} \mathrm{C}\right)$ (Fluka); for lipid characteristics using lipase $\left(1 \mathrm{mg} / \mathrm{ml}\right.$ at $\left.37^{\circ} \mathrm{C}\right)$ (Fluka)) and for carbohydrate characteristics using $\alpha$-amylase $(1 \mathrm{mg} / \mathrm{ml}$ at $25^{\circ} \mathrm{C}$ ) (Fluka). Briefly for any enzymatic treatment, the amount of enzyme used as indication i.e. $1 \mathrm{mg}$ of enzyme was added to $1 \mathrm{ml}$ of the culture filtrate, mixed well, and incubated at the appropriate temperature for $1 \mathrm{hr}$. The remaining anti-Vibrio harveyi PSU 2015 activity was then observed by the agar well diffusion method (Vijayan et al. 2006). Negative controls were also prepared using a similar procedure, except that the isolate W3 preparation was omitted (uninoculated medium). Positive controls were prepared without the addition of enzymes.

The heat stability of the anti-Vibrio harveyi compounds was separately tested by heating the culture filtrates ( 0.45 and $0.22 \mu \mathrm{m}$ ) of Pseudomonas sp. W3 in a water bath for 30 min at different temperatures; $50^{\circ} \mathrm{C}, 65^{\circ} \mathrm{C}, 75^{\circ} \mathrm{C}, 100^{\circ} \mathrm{C}$; and was also autoclaved at $121^{\circ} \mathrm{C}$ for 15 and $30 \mathrm{~min}$. For controls each culture filtrate was incubated at $30^{\circ} \mathrm{C}$ for 30 min. The anti-Vibrio harveyi PSU 2015 activity was tested by the agar well diffusion method.

The $\mathrm{pH}$ susceptibility of bioactive compounds from Pseudomonas sp. W3 against V. harveyi PSU 2015 was tested by adjusting the $\mathrm{pH}$ of each culture filtrate $(0.45$ and $0.22 \mu \mathrm{m}$ ) over the range of 1.0-10.0 with either $0.1 \mathrm{~N} \mathrm{HCl}$ or $0.1 \mathrm{NaOH}$ (Lee et al. 2004). Culture filtrates without adjustment of $\mathrm{pH}$ served as positive controls whereas negative controls were prepared using a similar procedure with treated set in uninoculated medium (FGM). The antiVibrio harveyi activity was tested by the agar well diffusion method.

\section{Statistical analysis}

Three replicates were used in each experiment, unless otherwise stated. All results were presented as means \pm their standard deviations. A One-way ANOVA (SPSS for windows version 15) was used to analyze statistical differences at a $p$-value $<0.05$ and mean comparisons were performed by the Duncan's multiple range test.

\section{RESULTS}

The inhibitory effect of antibiotics and culture samples of Pseudomonas sp. W3 against shrimp pathogens

Antibiotic susceptibility testing of the shrimp pathogen, $V$. harveyi is shown in Table 1 . All strains tested were susceptible to chloramphenicol, tetracycline, nalidixic acid, oxolinic acid and norfoxazine but resistant to kanamycin and ampicillin. Furazolidone and sulphamethoxazone gave intermediate zones of inhibition to strains AAHRC1 and AAHRC2. Table 2 shows that a $70 \mu \mathrm{l}$ of the culture supernatant from Pseudomonas sp. W3 inhibited the growth of the following shrimp pathogens; V. harveyi PSU 2015, $V$. harveyi AAHRC 1, $V$. harveyi AAHRC 2, $V$. parahaemolyticus AAHRC1, V. cholerae PSSCMI 0062 with clear zones in a size range of $13.7 \pm 0.8$ to $21.2 \pm 0.4$ $\mathrm{mm}$. The most sensitive strain was $V$. harveyi PSU 2015 while $V$. parahaemolyticus PSU 1681 was the most tolerant strain with a zone size of only $6.5 \pm 0.2 \mathrm{~mm}$.

There were very little significant differences between the inhibitory characteristics of the $0.45 \mu \mathrm{m}$ and the $0.22 \mu \mathrm{m}$ culture filtrates but there was a tendency for the $0.22 \mu \mathrm{m}$ filtrate to be less inhibitory than the $0.45 \mu \mathrm{m}$ culture filtrates. Moreover, in most cases the $0.22 \mu \mathrm{m}$ culture filtrate samples gave inhibition zone sizes that were 
Table 3. Comparison of the observation of lytic activity, against heat killed cells and live cells of Vibrio harveyi PSU 2015 by a $0.45 \mu \mathrm{m}$ culture filtrates obtained during growth of Pseudomonas sp. W3 culture.

\begin{tabular}{|c|c|c|c|c|c|}
\hline \multirow{2}{*}{$\begin{array}{c}\text { Incubation } \\
\text { time (hrs) }\end{array}$} & \multicolumn{5}{|c|}{ Bacteriolytic activity } \\
\cline { 2 - 6 } & Control & $\begin{array}{c}\text { 18 hrs culture } \\
\text { filtrate }\end{array}$ & $\begin{array}{c}\text { 24 hrs culture } \\
\text { filtrate }\end{array}$ & Control & 24 hrs culture filtrate \\
\hline 0 & - & - & - & - & - \\
\hline 2 & - & - & - & - & + \\
\hline 4 & - & - & + & - & + \\
\hline 6 & - & + & + & - & ++ \\
\hline 8 & - & + & + & - & + \\
\hline 10 & - & + & + & - & + \\
\hline
\end{tabular}

Cell lytic activity when compared with a control set (no addition of $0.45 \mu \mathrm{m}$ culture filtrate) was scored as follows: -, 0-24\%; +, 25-49\%; ++, 50-74 and,$+++ 75-100 \%$.

significantly less than those for the culture supernatant samples, especially the reductions of inhibition zone sizes with $V$. parahaemolyticus PSU1681, V. cholerae PSSCMI 0062 and $V$. harveyi PSU 2015 that were 100, 39 and 27\%, respectively.

\section{Effect of culture age on production of antivibrio compounds}

The $0.45 \mu \mathrm{m}$ culture filtrates from Pseudomonas sp. W3 grown in FGM medium plus $2 \% \mathrm{NaCl}$ under the optimal conditions showed that cells started to produce bioactive compounds that inhibited V. harveyi PSU 2015 when the cells were reaching the late log phase of growth at 12 hrs and the inhibition zone was $11.0 \pm 0.4 \mathrm{~mm}$ (Figure 1). After that cells in the early stationary phase (18 hrs) gave the highest activity $(16.9 \pm 0.8 \mathrm{~mm})$ against the target organism and then this significantly decreased $(p<0.05)$ to $15.8 \pm$ $0.4 \mathrm{~mm}$ at the late stationary phase (24 hrs).

\section{Assay of bacteriolytic activity}

The bacteriolytic activity of a $0.45 \mu \mathrm{m}$ culture filtrate from both 18 and 24 hrs Pseudomonas sp. W3 culture against heat killed cells of $V$. harveyi PSU 2015 is shown in Table 3. The 18 hrs filtrate had a low lytic activity (+) that was first observed at 6 hrs until the end of testing at 22 hrs. The 24 hrs culture filtrate W3 caused a low level of lysis after 4 hrs incubation and this increased to a higher level $(++)$ at 22 hrs. The bacterial cell-lytic activity of the culture filtrate
W3 was confirmed by SEM photomicrography (Figure 2). There were no changes to cell shape in the control set of heat killed cells throughout the 22 hrs testing period (Figure $2 \mathrm{a}$ and $2 \mathrm{~b}$ ). Some modified dead cells of the treatment set after 22 hrs of incubation appeared as ovoid or spherical shapes and the arrow shows the presence of holes (Figure 2d) whereas a treatment set at $0 \mathrm{hr}$ showed that most killed cells were rod shaped (Figure 2c).

The lytic activity of the 24 hrs culture filtrate W3 against live cells of $V$. harveyi PSU 2015 was evident after 4 hrs of incubation i.e. at the same time as with the heat killed cells but after that a higher lytic activity was found (Table 3). SEM photomicrographies of live cells in a treatment set after 22 hrs incubation showed holes (Figure 2f) while normal live cell shapes were found in the treatment at $0 \mathrm{hr}$ (Figure 2e). TEM photomicrographs strongly supported the finding that culture filtrate W3 in the treatment set after 22 hrs incubation caused live cells of V. harveyi PSU 2015 to lyse (Figure 3d) whereas only normal cells were found in a control set at both 0 and 22 hrs of incubation and also in a treatment set taken at $0 \mathrm{hr}$ of incubation (Figure 3a-c).

\section{Preliminary studies on the property of bioactive compounds from Pseudomonas sp. W3}

Most of the enzyme treatments caused some loss of inhibitory activity against $V$. harveyi PSU 2015 and this loss was significantly less $(\mathrm{p}<0.05)$ with the $0.22 \mu \mathrm{m}$ filtrate than with the $0.45 \mu \mathrm{m}$ filtrate (Table 4 ). We assume 
that some inhibitory compound, more sensitive to the enzyme treatments was removed by the smaller sized filter. This material was perhaps protein because treatment with any of the proteolytic enzymes caused a loss in inhibitory activity (19-27\%) from the $0.45 \mu \mathrm{m}$ filtrate; and the maximum loss of the $0.22 \mu \mathrm{m}$ culture filtrate treated with $\alpha$-chymotrypsin was only $8 \%$. The biggest reduction (27\% loss) occurred when the $0.45 \mu \mathrm{m}$ filtrate was treated with $\alpha$ chymotrypsin. However, in most cases for the $0.45 \mu \mathrm{m}$ filtrate, more than $78 \%$ of the activity remained after enzyme treatment and for the $0.22 \mu \mathrm{m}$ filtrate more than $90 \%$ of the activity remained after enzyme treatment. The other enzyme treatments lysozyme, lipase and $\alpha$-amylase caused a 19, 17 and $16 \%$ loss of activity with the $0.45 \mu \mathrm{m}$ filtrate and a 5, 5 and $8 \%$ loss with the $0.22 \mu \mathrm{m}$ filtrate, respectively.

The inhibitory activity of either culture filtrate was not affected by heating up to $100^{\circ} \mathrm{C}$ but heating in an autoclave at $121^{\circ} \mathrm{C}$ for 30 min caused a $20 \%$ loss of activity in the $0.45 \mu \mathrm{m}$ filtrate and a 9\% loss in the $0.22 \mu \mathrm{m}$ filtrate.

The optimum $\mathrm{pH}$ for the inhibitory activity of the $0.45 \mu \mathrm{m}$ filtrate occurred at a pH between 6 and 7. At a pH of 4, 2 and 1 activity declined by $19 \%, 24 \%$ and $69 \%$ and at a $\mathrm{pH}$ of 8 and 10 activity declined $28 \%$ and 35\%, respectively. The effect of the $\mathrm{pH}$ on the activity of the $0.22 \mu \mathrm{m}$ filtrate was minimal, except for the $\mathrm{pH} 1$ sample (40\% loss of activity).

\section{DISCUSSION}

\section{Inhibitory effect of commercial antibiotics and bioactive compounds produced by the isolate W3 against vibrios}

Most of the antibiotics used could cause inhibition of all tested strains of $V$. harveyi (Table 1), Hence antibiotics could be used to control $V$. harveyi infections that affect aquaculture in Thailand. However, some of them such as chloramphenicol, furazolidone, tetracycline and oxonilic acid are now banned for use in aquaculture as previously mentioned. In general, $\beta$-lactam antibiotics such as ampicillin are preferred for use by shrimp farmers to treat luminous vibriosis disease since these groups of antibiotics do not cause significant side effects (Teo et al. 2002). Unfortunately, all tested strains in this study were resistant to ampicillin and this result is in agreement with Teo et al. (2002) who reported that many types of $\beta$-lactam antibiotics were no longer able to prevent vibriosis. In Thailand sulphamethoxazole is normally used in hatcheries against Vibrio sp.; however, in this study it showed only moderate ability to inhibit shrimp pathogens. Results in this study were similar to previous studies (Otta et al. 2001; Musa et al. 2008). Based on the above results, only a limited number of antibiotics, such as nalidixic acid and norfoxazine, could be used for treating shrimp diseases. However, resistance to quinolones in the form of nalidixic acid and norfoxazine has been observed in target pathogens

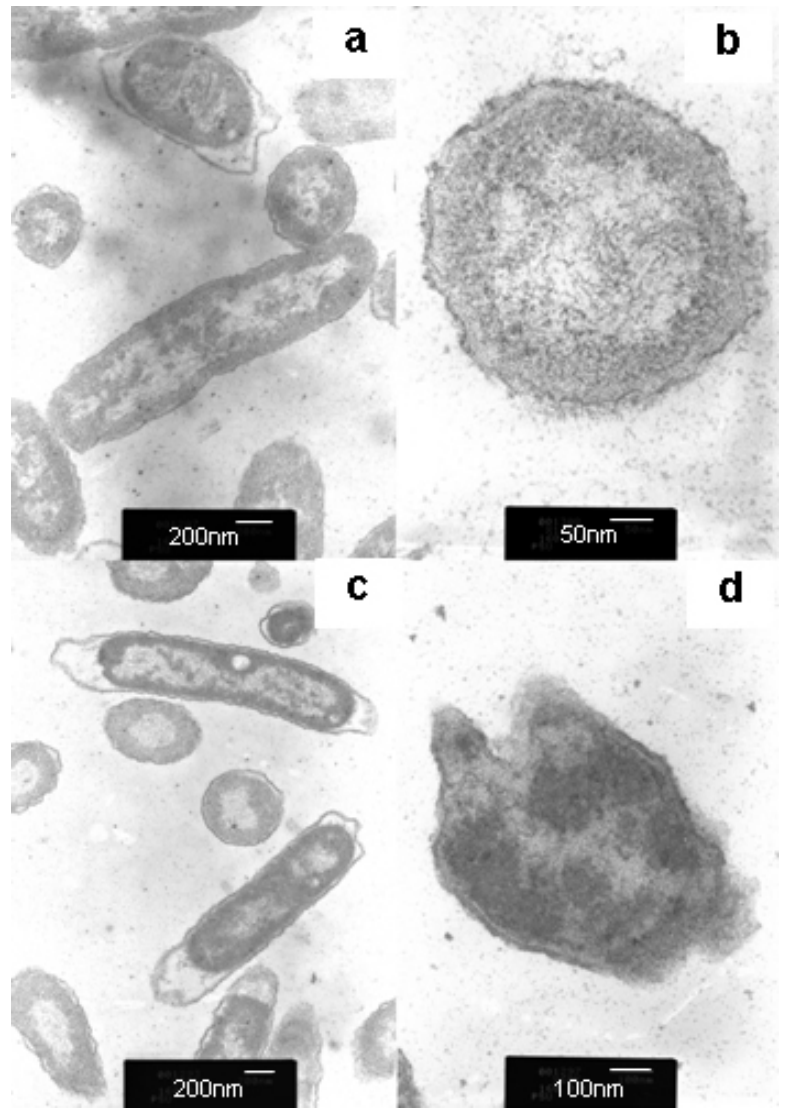

Figure 3. TEM photomicrographs showing altered structures of live cells (a, b, c and d) of Vibrio harveyi PSU 2015 by a 24 hrs culture filtrate $(0.45 \mu \mathrm{m})$ of Pseudomonas sp. W3; (a) control (no addition) at $0 \mathrm{hr}$; (b) control at $22 \mathrm{hrs}$; (c) treatment at 0 $\mathrm{hr}$; (d) treatment after $22 \mathrm{hrs}$ incubation.

due to the quinolones act against DNA-metabolism and repair attempts by the bacteria can lead to the formation of resistant mutants (WHO, 1998; Gräslund, S. and Bengtsson, 2001). Therefore, the use of new inhibitory compounds needs to be investigated to combat luminous vibriosis.

Many studies have shown that compounds produced by bacteria could be used to inhibit bacterial pathogens in aquaculture systems (Alavandi et al. 2004; Vijayan et al. 2006). The use of such compounds to control shrimp pathogens by means other than by the use of antibiotics is now gaining acceptance in shrimp farming as it can be a better and more cost effective alternative than administering antibiotics to manage the health of shrimps (Verschuere et al. 2000; Alavandi et al. 2004).

Late log phase cultures of Pseudomonas sp. W3 inhibited a variety of shrimp pathogens tested in vitro and a maximum activity was present during their early stationary growth phase (Figure 1). This indicated that the antivibrio compounds could be "secondary metabolites". The culture supernatant and culture filtrates $(0.45 \mu \mathrm{m}$ and $0.22 \mu \mathrm{m}$ pore 
Table 4. Inhibition of Vibrio harveyi PSU 2015 by $0.45 \mu \mathrm{m}$ and $0.22 \mu \mathrm{m}$ culture filtrates from Pseudomonas sp. W3.

\begin{tabular}{|c|c|c|}
\hline \multirow{2}{*}{ Treatment } & \multicolumn{2}{|c|}{ Inhibition zone (mm) } \\
\hline & $0.45 \mu \mathrm{m}$ culture filtrate & $0.22 \mu \mathrm{m}$ culture filtrate \\
\hline \multicolumn{3}{|l|}{ Enzyme } \\
\hline Control & $17.8 \pm 0.3^{\mathrm{a}}$ & $15.2 \pm 0.4^{\mathrm{a}}$ \\
\hline Proteinase $\mathrm{K}$ & $13.8 \pm 0.2^{\mathrm{bc}}$ & $14.7 \pm 0.7^{\mathrm{abc}}$ \\
\hline Pronase & $13.9 \pm 0.4^{b c}$ & $14.4 \pm 0.5^{\mathrm{abc}}$ \\
\hline Pepsin & $14.4 \pm 0.2^{\mathrm{bc}}$ & $14.3 \pm 0.2^{\mathrm{abc}}$ \\
\hline a-chymotrypsin & $13.0 \pm 0.2^{c}$ & $14.0 \pm 0.5^{\mathrm{c}}$ \\
\hline Trypsin & $14.0 \pm 0.6^{\mathrm{bc}}$ & $15.1 \pm 0.7^{\mathrm{ab}}$ \\
\hline Lysozyme & $14.5 \pm 0.2^{b c}$ & $14.8 \pm 0.2^{\mathrm{abc}}$ \\
\hline Lipase & $14.8 \pm 0.4^{b}$ & $14.4 \pm 0.4^{\mathrm{abc}}$ \\
\hline$\alpha$-amylase & $15.0 \pm 0.4^{b}$ & $14.0 \pm 0.4^{\mathrm{bc}}$ \\
\hline \multicolumn{3}{|c|}{ Temperature of incubation $\left({ }^{\circ} \mathrm{C}\right)$} \\
\hline Control (30) & $18.0 \pm 0.5^{\mathrm{a}}$ & $15.4 \pm 0.4^{\mathrm{a}}$ \\
\hline 50 & $17.5 \pm 0.5^{\mathrm{a}}$ & $15.3 \pm 0.3^{a}$ \\
\hline 65 & $16.5 \pm 0.4^{b}$ & $14.7 \pm 0.1^{\mathrm{ab}}$ \\
\hline 75 & $15.9 \pm 0.5^{\mathrm{b}}$ & $15.0 \pm 0.4^{\mathrm{ab}}$ \\
\hline 100 & $16.2 \pm 0.3^{b}$ & $14.7 \pm 0.4^{\mathrm{ab}}$ \\
\hline Autoclave $\left(121^{\circ} \mathrm{C}, 15 \mathrm{~min}\right)$ & $15.1 \pm 0.4^{\mathrm{C}}$ & $14.7 \pm 0.2^{\mathrm{ab}}$ \\
\hline Autoclave $\left(121^{\circ} \mathrm{C}, 30 \mathrm{~min}\right)$ & $14.3 \pm 0.2^{d}$ & $14.0 \pm 0.7^{b}$ \\
\hline \multicolumn{3}{|l|}{$\mathrm{pH}$} \\
\hline Control (pH 7.40) & $17.1 \pm 0.5^{\mathrm{a}}$ & $16.8 \pm 0.7^{\mathrm{a}}$ \\
\hline 1 & $5.3 \pm 0.5^{f}$ & $10.1 \pm 0.7^{\mathrm{c}}$ \\
\hline 2 & $13.1 \pm 0.4^{\mathrm{cd}}$ & $15.5 \pm 0.7^{b}$ \\
\hline 3 & $13.3 \pm 0.5^{\mathrm{c}}$ & $15.4 \pm 0.5^{b}$ \\
\hline 4 & $13.9 \pm 0.5^{\mathrm{bc}}$ & $16.1 \pm 0.3^{\mathrm{ab}}$ \\
\hline 5 & $14.4 \pm 0.5^{\mathrm{bc}}$ & $15.6 \pm 0.8^{a b}$ \\
\hline 6 & $16.5 \pm 0.3^{b}$ & $16.0 \pm 0.5^{\mathrm{ab}}$ \\
\hline 7 & $16.3 \pm 0.3^{b}$ & $15.5 \pm 0.8^{\mathrm{ab}}$ \\
\hline 8 & $12.4 \pm 0.4^{d}$ & $15.5 \pm 0.3^{\mathrm{ab}}$ \\
\hline 9 & $12.2 \pm 0.4^{d}$ & $14.9 \pm 0.6^{b}$ \\
\hline 10 & $11.1 \pm 0.4^{\mathrm{e}}$ & $14.9 \pm 0.8^{\mathrm{b}}$ \\
\hline
\end{tabular}

Mean value \pm standard deviation of nine observations for enzyme treatments and $\mathrm{pH}$ activities; three observations for temperature. Different letters in the same column denote significant differences $(p<$ 0.05).

size filters) contained inhibitors of the growth of most shrimp pathogens tested with different degrees of inhibition although none of the culture filtrate inhibited the growth of one V. parahaemolyticus strain PSU1681 (Table 2).
Production of extracellular antivibrio substances by another strain of pseudomonad, Pseudomonas I-2, was also observed (Chythanya et al. 2002). The use of the agar well diffusion technique indicated that some antivibrio 
compounds produced by the isolate W3 were water soluble compounds as they readily diffused through the agar medium. Previous studies have reported that Pseudomonas spp. produce water soluble bioactive compounds that are secreted into the media such as a group of phenazines (Price-Whelan et al. 2006).

The unfiltered culture supernatant produced the best inhibition of $V$. harveyi PSU 2015 and $V$. cholerae PSSCMI 0062 followed by the $0.45 \mu \mathrm{m}$ filtrate while the $0.22 \mu \mathrm{m}$ culture filtrate was the least inhibitory. This indicated that some of the inhibitory activity was associated with particulate matter that was removed by the filtration process and only dissolved and soluble colloidal organic matter was present in the 0.22 filtrate. It has been recommended that a $0.22 \mu \mathrm{m}$ membrane can be used to separate proteins of low molecular weight or peptides from larger molecules (Thermo Fisher Scientific Inc, 2008).

\section{Preliminary studies on the property of bioactive compounds produced by the isolate W3}

In this study, some of the growth inhibitory compounds may be bacteriolytic as rod shaped cells were changed to ovoid cells (Table 3, Figure 2d and 2f). However, although the isolate W3 showed lysis against dead and live cells of $V$. harveyi PSU 2015 neither were completely lysed after 22 hrs incubation. This might be due to an attack on the cell envelope structure of $V$. harveyi (Figure 2). In contrast, $a$ Pseudomonas sp. isolated from the surface seawater of Japan produced an enzyme that completely lysed the dead cells of Vibrio parahaemolyticus VPHK-46 (Than et al. 2004). Our previous study indicated that Pseudomonas sp. W3 produces an extracellular alkaline protease (Rattanachuay et al. 2007). There is evidence from the present study that at least some of the inhibitory activity may be associated with a proteolytic enzyme. This work was similar to that reported by Shastry and Prasad (2002) who showed that Pseudomonas sp. (CL 1457) produced an extracellular alkaline protease against heat killed cells of Xanthomonas campestris.

In general, bacteriolytic enzymes are classified into two major groups; peptidoglycan hydrolases (i.e. Nacetylmuramidases, $\mathrm{N}$-acetyl glucosamidases, etc.) and proteolytic enzymes (Than et al. 2004). Results in Table 4 indicate that some loss of anti-Vibrio harveyi activity of the isolate W3 was caused by proteolytic enzymes and lysozyme (N-acetylmuramidase). Hence, it may be possible the isolate W3 produced both types of lytic enzymes. The cell walls of Gram negative bacteria are surrounded by an outer membrane consisting of lipopolysaccharides, phospholipids and lipoproteins and thus they are less sensitive to bacteriolytic enzymes than Gram positive bacteria (Wang et al. 2008). Only a few lytic enzymes have been reported to lyse cells of Gram negative bacteria (Shastry and Prasad, 2002); therefore, it is interesting that the isolate W3 produced lytic enzymes that acted to remove the outer membrane as some leaky cells can be seen by electron microscopy (arrows in Figure 2d and 2f; Figure 3d). After removal of their outer membrane Vibrio cells become more easily damaged by other bioactive compounds produced by the isolate W3.

A higher lytic activity of the isolate W3 against $V$. harveyi PSU 2015 was found in a 24 hrs culture filtrate when compared to an 18 hrs culture filtrate. This may be caused by the lytic enzymes being produced during the early stationary phase of bacterial growth (Figure 1) in a similar way to the yeast lytic enzymes produced by Oenococcus oeni (Guilloux-Benatier et al. 2000). It was surprising to note that the isolate W3 showed a higher lytic activity on living cells compared to dead cells of V. harveyi PSU 2015 during the 6-10 hrs testing time (Table 3). This may imply that the lytic enzymes work better when cell walls are being produced actively. It has been recognized that heating of live cells helps to disrupt the outer membrane of Gram negative bacteria, and this can allow hydrolytic enzymes a better access to the bacterial peptidoglycan (Ryazanova et al. 2005). However, the results in this study showed that no disruption of the outer membrane occurred in dead cells of the control at 0 and $22 \mathrm{hrs}$ (Figure 2a and 2b). This might explain that live cells were killed by heating at only $50^{\circ} \mathrm{C}$ for 30 min while Ryazanova et al. (2005) live cells were killed by autoclaving $\left(121^{\circ} \mathrm{C}\right)$. It will be necessary to carry out further studies to clearly identify the mode of action of these lytic enzymes.

The results from Table 4 indicate that some anti-Vibrio harveyi compounds present on particulate matter are destroyed by treating with proteolytic enzymes, lysozyme, lipase and amylase and are destroyed by autoclaving at $121^{\circ} \mathrm{C}$ for $30 \mathrm{~min}$. The inhibitory compounds left in the $0.22 \mu \mathrm{m}$ filtrate were not protein, were possibly not related to carbohydrate or lipid moieties and not heat labile, had $\mathrm{pH}$ stability ( $\mathrm{pH} 4-8)$ and are small molecular weight compounds (Table 4). This was in agreement with Chythanya et al. (2002) who reported Pseudomonas I-2 produced an antibacterial compound responsible for the inhibition of vibrios i.e. V. harveyi, V. parahaemolyticus, etc. and that compound may be pyocyanine, which is a nonproteinacious, chloroform-soluble blue pigment, heat stable with low molecular weight. Vijayan et al. (2006) also found that Pseudomonas PS-102 inhibited the growth of $V$. harveyi in a similar manner to Pseudomonas I-2 by a cell free supernatant that contained a heat stable compound and it was resistant to proteolytic, lipolytic and amylolytic enzymes. The property of heat stability would be useful during the production of shrimp feed, as at certain stages of production it is exposed to higher temperatures. It is of interest that some different activities were found for the isolate $\mathrm{W} 3$ as this bacterium produced more than one bioactive compound that were active over a wide range of $\mathrm{pH}$ and also produced lytic enzymes (Table 2, Table 3, Table 4, Figure 2 and Figure 3). This means that the inhibitory compounds produced by the isolate W3 may be alternative compounds for use in shrimp cultivation. 
In conclusion, the results from this study indicate that Pseudomonas sp. W3 produced more than one extracellular antibacterial substance responsible for inhibiting the growth of shrimp pathogenic bacteria and caused cell lysis of $V$. harveyi. It can be concluded that some of the compounds that inhibit the growth of $V$. harveyi, are proteinaceous while the most active are heat stable, $\mathrm{pH}$ tolerant and mostly resistant to various enzymes (lysozyme, proteolytic, lipolytic and amylolytic enzymes) and have a small molecular weight. Our work is continuing to characterize the target of these inhibitory compounds and to further explore the potential of Pseudomonas sp. W3 for use in the shrimp aquaculture industry.

\section{ACKNOWLEDGMENTS}

The authors would like to thank Aquatic Animal Help Research Center (AAHRC) and Assoc. Prof. Dr. Varaporn Vuddhakul for providing shrimp pathogenic bacteria used in this study and also Dr. Brian Hodgson for a critical reading of our manuscript and assistance with the English.

\section{REFERENCES}

ALAVANDI, S.V.; VIJAYAN, K.K.; SANTIAGO, T.C.; POORNIMA, M.; JITHENDRAN, K.P.; ALI, S.A. and RAJAN, J.J.S. Evaluation of Pseudomonas sp. PM 11 and Vibrio fluvialis PM 17 on immune indices of tiger shrimp, Penaeus monodon. Fish and Shellfish Immunology, August 2004, vol. 17, no. 2, p. 115-120.

AUSTIN, B. and ZHANG, X.H. Vibrio harveyi: a significant pathogen of marine vertebrates and invertebrates. Letters in Applied Microbiology, 2006, vol. 43, no. 2, p. 119-124.

CHARI, P.V.B. and DUBEY, S.K. Rapid and specific detection of luminous and non-luminous Vibrio harveyi isolates by PCR amplification. Current Science, 2006, vol. 90, no. 8, p. 1105-1108.

CHYTHANYA, R.; KARUNASAGAR, I. and KARUNASAGAR, I. Inhibition of shrimp pathogenic vibrios by a marine Pseudomonas I-2 strain. Aquaculture, 2002, vol. 208, no. 1-2, p. 1-10.

FRAZIER, William C. and RUPP, Philip. Studies on the proteolytic bacteria of milk III. Action of proteolytic bacteria of milk on casein and gelatin. Journal of Bacteriology, 1982, vol. 16, no. 3, p. 187-196.

GOMEZ-GIL, Bruno; ROQUE, Ana and TURNBULL, James F. The use and selection of probiotic bacteria for use in the culture of larval aquatic organisms. Aquaculture, 2000, vol. 191, no. 1-3, p. 259-270.

GRÄSLUND, S. and BENGTSSON, B.E. Chemicals and biological products used in south-east Asian shrimp farming, and their potential impact on the environment-a review. The Science of the Total Environment, 2001, vol. 280, no. 1-3, p. 93-131.

GRÄSLUND, S.; KARIN, K. and WONGTAVATCHAI, J. Responsible use of antibiotic in shrimp farming. Aquaculture Asia, 2002, vol. 7, no. 3, p. 17.

GUILLOUX-BENATIER, M.; PAGEAULT, O.; MAN, A. and FEUILLAT, M. Lysis of yeast cells by Oenococcus oeni enzymes. Journal of Industrial Microbiology and Biotechnology, 2000, vol. 25, no. 4, p. 193-197.

HOLMSTRÖM, Katrin; GRÄSLUND, Sara; WAHLSTRÖM, Ann; POUNGSHOMPOO, Somlak; BENGTSSON, Bengt-Erik and KANTSKY, Nils. Antibiotic use in shrimp farming and implications for environmental impacts and human health. Journal of Food Science, 2003, vol. 38, no. 3, p. 255-266.

HUYS, Geert; BARTIE, Kerry; CNOCKAERT, Margo; OANH, Dang Thi Hoang; PHUONG, Nguyen Thanh; SOMSIRI, Temdoung; CHINABUT, Supranee; YUSOFF, Fatimah; SHARIFF, Mohamed; GIACOMINI, Mauro; TEALE, Alan and SWINGS, Jean. Biodiversity of chloramphenicol-resistant mesophilic heterotrophs from Southeast Asian aquaculture environments. Research in Microbiology, 2007, vol. 158, no. 3, p. 228-235.

KUMAR, Manoj; LEON, Vladimir; MATERANO, Angela De Sisto; ILZINS, Olaf A. and LUIS, Luis. Biosurfactant production and hydrocarbon-degradation by halotolerant and thermotolerant Pseudomonas sp. World Journal of Microbiology and Biotechnology, 2008, vol. 24, no. 7, p. 1047-1057.

LEE, Ching-Fu; HAN, Chien-Kuo and TSAU, Jya-Li. In vitro inhibitory activity of Chinese leek extract against Campylobacter species. International Journal of Food Microbiology, 2004, vol. 94, no. 2, p. 169-174.

MUSA, Najiah; WEI, Lee Seong and WEE, Wendy. Phenotypic and genotypic characteristics of Vibrio harveyi isolated from black tiger shimp (Penaeus monodon). World Applied Sciences Journal, 2008, vol. 3, no. 6, p. 885-902.

NIMRAT, Subuntith; BART, Amrit N.; KEATSAKSIT, Aritsara and VUTHIPHANDCHAI, Verapong. Microbial flora of spermatophores from black tiger shrimp (Penaeus monodon) declines over long-term cryostorage. Aquaculture, 2008, vol. 274, no. 2-4, p. 247-253.

NIWA, Takashi; KAWAMURA, Yoshiaki.; KATAGIRI, Yoshihiro Y. and EZAKI, Takayuki. Lytic enzyme, labiase for a broad range of Gram-positive bacteria and its application to analyze functional DNA/RNA. Journal of Microbiological Methods, 2005, vol. 61, no. 2, p. 251-260.

OTTA, S.K.; KARUNASAGAR, I. and KARUNASAGAR, I. Bacteriological study of shrimp, 
Penaeus monodon Fabricius, hatcheries in India. Journal of Applied Ichthyology, 2001, vol. 17, no. 2, p. 59-63.

PRICE-WHELAN, Alexa; DIETRICH, Lars E.P. and NEWMAN, Dianne K. Rethinking 'secondary' metabolism: physiological roles for phenazine antibiotics. Nature Chemical Biology, 2006, vol. 2, no. 2, p. 71-78.

RATTANACHUAY, Pattamarat; KANTACHOTE, Duangporn and SUNTINANALERT, Prasert. Selection of proteolytic bacteria with ability to inhibit Vibrio harveyi during white shrimp (Litopenaeus vannamei) cultivation. The Songklanakarin Journal of Science and Technology, 2007, vol. 29, no. 2, p. 235-243.

RYAZANOVA, L.P.; LEDOVA, L.A.; TSURIKOVA, N.V.; STEPNAYA, O.A.; SINITSYN, A.P. and KULAEV, I.S. Effect of the proteolytic enzymes of Bacillus licheniformis and the lysoamidase of Lysobacter sp. XL1 on Proteus vulgaris and Proteus mirabilis cells. Applied Biochemistry and Microbiology, 2005, vol. 41, no. 5, p. 490-494.

SAKAMI, Tomoko; FUJOKA, Yoshimi and SHIMODA, Toru. Comparison of microbial community structures in intensive and extensive shrimp culture ponds and a mangrove area in Thailand. Fisheries Science, 2008, vol. 74, no. 4, p. 889-898.

SHASTRY, S. and PRASAD, M.S. Extracellular protease from Pseudomonas sp. (CL 1457) active against Xanthomonas campestris. Process Biochemistry, 2002, vol. 37, no. 6, p. 611-621.

SIVAPRAKASAM, Senthilkumar; MAHADEVAN, Surianarayanan and GOPALARAMAN, Swaminathan. Oxygen mass transfer studies on batch cultivation of $P$. aeruginosa in a biocalorimeter. Electronic Journal of Biotechnology, 2008, vol. 11, no. 1, 13 pp.

SIVAPRAKASAM, S.; MAHADEVAN, S. and GOPALRAMAN, S. Oxygen mass transfer studies on batch cultivation of $P$. aeruginosa in a biocalorimeter. Electronic Journal of Biotechnology [online]. 15 January 2008, vol. 11, no. 1 [cited date]. Available from Internet: http://www.ejbiotechnology.info/content/vol11/issue1/full/ 15/index.html. ISSN 0717-3458

TEO, Jeanette W.P.; TAN, Theresa M.C. and CHIT, Laa Poh. Genetic determinants of tetracycline resistance in Vibrio harveyi. Antimicrobial Agents and Chemotherapy, 2002, vol. 46, no. 2, p. 1038-1045.

THAN, Phyu Phyu; DEL CASTILLO, Carmelo S.; YOSHIKAWA, Takeshi and SAKATA, Taizo. Extracellular protease production of bacteriolytic bacteria isolated from marine environments. Fisheries Science, 2004, vol. 70, no. 4, p. 659-666.
THERMO FISHER SCIENTIFIC Inc., 2008 [cite $18^{\text {th }}$ October 2008], Membranes, filter and transfer buffer. Available from Internet: httn://www niercenet com/nroducts.

Note: Electronic Journal of Biotechnology is not responsible if on-line references cited on manuscripts are not an Supported by UNESCO / MIRCEN network.

VERSCHUERE, Laurent; ROMBAUT, Geert; SORGELOOS, Patrick and VERSTRAETE, Willy. Probiotic bacteria as biological control agents in aquaculture. Microbiology and Molecular Biology Reviews, 2000, vol. 64, no. 4, p. 655-671.

VIJAYAN, K.K.; SINGH, I.S.B.; JAYAPRAKASH, N.S.; ALAVANDI, S.V.; PAI, S.S.; PREE, R.; RAJAN, J.J.S. and SANTIAGO, T.C. A brackishwater isolate of Pseudomonas PS-102, a potential antagonistic bacterium against pathogenic vibrios in penaeid and non-penaeid rearing systems. Aquaculture, 2006, vol. 251, no. 2-4, p. 192-200.

VINOD, M.G.; SHIVU, M.M.; UMESHA, K.R.; RAJEEVA, B.C.; KROHNE, G.; KARUNASAGAR, I. and KARUNASAGAR, I. Isolation of Vibrio harveyi bacteriophage with a potential for biocontrol of luminous vibriosis in hatchery environments. Aquaculture, 2005, vol. 225, no. 1-4, p. 117-124.

WANG, S.; KONG, J. and ZHANG, X. Identification and characterization of the two-component cell lysis cassette encoded by temperate bacteriophage $\varphi$ PYB5 of Lactobacillus fermentum. Journal of Applied Microbiology, May 2008, vol. 105, no. 6, p. 1939-1944.

WAHID, M. Iftekharul; YOSHIKAWA, Takeshi and SAKATA, Taizo. Bacteriolytic activity and growth of marine isolates of labyrinthulids on dead bacterial cells. Fisheries Science, 2007, vol. 73, no. 6, p. 1286-1294.

WHO. Use of quinolines in food animals and potential impact on human health, Report of a WHO Meeting Geneva, Switzerland, 2-5 June, 1998. WHO/EMC/ZDI/98.10. Available from Internet: http://www.who.int/emc

WON, Kyoung Mi and PARK, Soo Il. Pathogenicity of Vibrio harveyi to cultured marine fishes in Korea. Aquaculture, 2008, vol. 285, no. 1-4, p. 8-13. 